\title{
Mental health, by Jane Austen
}

\author{
Jean Harris Hendriks
}

In the year of the Collego's 150th onniversory, the Prealdent Invited easoys with the tith The Thercpoutic Elfects on Pyychiotile Patients of a Plecisont and Congonial Environment. Witiors were akked to condider "current literature".

Jane Austen knew the pleasant and congenial environment of Belgravia in 1811 when she corrected the proofs of Sense and Sensiblity at 64 Sloane Street, home of her brother Henry Austen and his wife Eliza (widow of the Comte de Feullide who had been guillotined in 1794, two years after the French Revolution). In 1815, awaiting the publication of Emma she had stayed with them at 33 Hans Crescent. Each of these novels illustrates that, had she been in Belgrave Square today, she would have understood the essay title and could have written cogently, for her novels are indeed literature and the issues which they address most certainly are current.

She describes her ideal of a substantial institution in Mansfleld Park, where there were "no signs of contention; no raised volces, no abrupt bursts, no tread of violence was ever heard; all proceeded in a regular course of cheerful orderliness, everybody had their due importance, everybody's feelings were consulted. If tenderness could ever be supposed wanting, good sense and good breeding supplied its place".

Jane Austen's pleasant environment encompassed regular meals, comfortable clothing, unobtrustve avallability of servants and equanimity of mind as to income (or at least the prospects of inheriting income). Space and privacy are of the essence: "an interval of meditation, serious and grateful, was the best corrective of everything dangerous in such high wrought felicity; and she went to her room, and grew steadfast and fearless in the thankfulness of her enjoyment" (Persuasion). The essential is a room of one's own.

This world does allow vulnerable, difficult individuals independence, a sense of being valued and autonomous. In it lives $\mathrm{Mr}$ Woodhouse, father of Emma, hypochondriac, depressed, chronically anxious, obsessional.
His asylum is his home. His creator says he is "unfit for any acquaintance but such as would visit him on his own terms". He fusses over his food, won't let his friends eat. "An egg bolled soft is not unwholesome... you need not be afraid...". When a young lady of his acquaintance is frightened by gypsies, Mr Woodhouse "trembled as he sat" and "would scarcely be satisfied without Emma promising never to go beyond the shrubbery again".

Jane Austen delineates the small world in which Mr Woodhouse and his counterpart Miss Jane Bates, an impoverished clergyman's daughter, with pressure of talk and an ailing mother, are contained, sustained and respected. Miss Bates and her mother receive care in the community in the way of visits, presents of legs of pork and apples, transport and entertainment with the constant assurance that this is a sign of their value, not of their dependence.

But the lives of relatives are constrained in ways in which they do not recognise. Emma is held to her home by her father's anxiety, a leash which prevents her from being away for more than two hours at a time. Her marriage, a climax of the novel, takes place only because Mr Woodhouse regards a husband to his daughter as a protection against poultry thefts. Jane Fairfax, Miss Bates's niece, pines throughout the novel. Her aunt says, "She really eats nothing - makes such a shocking breakfast, you would be quite frightened if you saw it". Her pallor is regarded as ladylike - she is probably anorexic.

From Jane Austen we learn what researchers on psychiatric care tell us today. A pleasant and congenial environment, large or small in scale, requires skdll and knowledge, architecture, gardening, furniture and constant maintenance. Jane Austen stresses order and cleanliness. There must be Individual care and concern between human beings and a mutual respect of the kind which enables the Bates family to feel loved and valued within their community. There must be time, thought and leisure for detalled and exquisite concern regarding the grief, terror 
and vulnerability of our fellow human beings. We must recognise that relattves are vulnerable and that reliable, round the clock service is taken for granted and obtained for low wages.

Jane Austen would not have completed her novels had she not relattves who were of substance, who could sustain and support her, both in London and in her country home.
When considering the current costs of care in the community, psychiatrists should indeed review the literature.

Jean Harris Hendriks, Consultant Psychiatrist, Child and Family Service, South Bedfordshtre Community Health Trust, Dunstable Health Centre, Dunstable LU6 3SU

\section{Jones the patient}

Rosclind Ramsay reviows Hollywood's lotest waning to poychiatilists.

Another film about psychiatrists and psychiatric patients has been showing in Britain. At the première of Mr Jones, Richard Gere, who stars in the leading role spoke about "working hard" to get the role "symptomatically and emotionally correct". Mr Jones has bipolar illness and the film allows the audience a vivid look at how the illness affects a person. The history of the presenting condition begins with $\mathbf{M r}$ Jones, expanstve and grandiose, asking a workmate "Do you ever feel like flying?" Minutes later Mr Jones has climbed to the top of the roof where they are working, saying "I'm going to fly..."

Prevented from leaping to his death, $\mathrm{Mr}$ Jones finds himself a patient in an American state mental hospital. The senior psychiatrist, overworked and cynical, explains to visiting medical students that times are difficult, and resources scarce. The doctor's job is simply to "evaluate, medicate and vacate". The students join a round of patients in seclusion. They see Mr Jones, lying on a bed, his ankles and wrists in handcuffs. It is time to medicate him forcibly: "He won't bite, we hope".

But this is more than a film describing the life of a person with bipolar lliness, or the philosophy of care in mental health services. In best Hollywood style it is also a fllm about a relationship between two people, in this case a man with bipolar illness and the young female psychiatrist responsible for his care. Mr Jones is intrustve but engaging, a textbook case of infectious gaiety, and breaks through the psychiatrist's professional defences. We see his doctor as a person with her own feelings and needs. In one scene in which staff and patients are mingling $\mathrm{Mr}$ Jones poses as a doctor and pointing to the three people talking together, he asks his visitor which one is the patient. The visitor identifies the psychiatrist.

The psychiatrist's thinking, initially driven by her wish to establish a therapeutic relationship with the patient and to understand his symptoms, slips into a less professional role when she starts to investigate his past. Working more as a private detecttve than as a psychiatrist she visits his ex-wife. Roles between doctor and patient reverse when Mr Jones rescues his psychiatrist from a violent incident with another patient on the ward and asks her if she is OK. The other doctors in the hospital are busy and although they are perhaps aware that something is happening between $\mathbf{M r}$ Jones and their colleague, they are not able to offer guidance to the young woman. The drama escalates until the doctors intervene, telling her not to see Mr Jones and to transfer him to another hospital.

The film may be looking at mania through rose-tinted glasses as $\mathbf{M r}$ Jones sweeps his doctor off her pedestal, but it does illustrate some of the difficulties psychiatrists face when developing rapport with patients. Her situation is made worse because she is too busy treating patients to consider her own need for support from her peers or from the senior psychiatrist. Although she has a high reputation in the hospital, she fails in the task of maintaining 